\title{
PEMANFAATAN VCO DAN EKSTRAK BUNGA KENANGA DALAM PEMBUATAN SABUN ANTIBAKTERI DI DESA ABABI KECAMATAN ABANG KARANGASEM
}

\author{
W.S. Rita ${ }^{1}$, I.W. Suirta ${ }^{2}$, E. Sahara ${ }^{3}$, I.A.R.A. Asih ${ }^{4}$
}

\begin{abstract}
ABSTRAK
Virgin Coconut Oil (VCO) dan ekstrak bunga kenanga dapat digunakan sebagai alternatif pengganti antibakteri sintetik dalam pembuatan sabun mandi padat transparan. Pengabdian ini bertujuan untuk membuat sabun antibakteri dengan memanfaatkan bahan aktif bakteri dari VCO dan ekstrak bunga kenanga. Sabun dibuat dengan mereaksikan VCO, minyak kelapa, asam sterat dengan suatu basa $(\mathrm{NaOH})$, selanjutnya ditambahkan bahan-bahan lain seperti sukrosa dan gliserin untuk membuat sabun yang transaparan. Ekstrak kenanga ditambahkan juga sebagai bahan aktif antibakteri dan sebagai pewangi. Produk yang dihasilkan beruba sabun transparan antibakteri yang mana sabun tersebut telah memenuhi Standar Nasional Indonesia (SNI). Masyarakat yang ditargetkan pada pelatihan pembuatan sabun adalah PKK dan Kelompok Perempuan Petani di Desa Ababi, Kecamatan Abang, Kabupaten Karangasem. Hasil pelatihan menunjukkan bahwa ada peningkatan wawasan peserta tentang sabun antibakteri dan cara membuatnya.
\end{abstract}

Kata kunci : Sabun, Antibakteri, Bunga Kenanga, VCO

\begin{abstract}
Virgin Coconut Oil (VCO) and cananga flower extract can be used as synthetic antibacterial substitutes in the manufacture of transparent solid bath soap. This service aims to make antibacterial soap by utilizing bacterial active ingredients from VCO and cananga flower extract. Soap was made by reacting VCO, coconut oil, steric acid with a base $(\mathrm{NaOH})$, then other ingredients such as sucrose and glycerin are added to make transparent soap. Cananga extract was also added as an antibacterial active ingredient and as a fragrance. The product produced has antibacterial transparent soap which has met the Indonesian National Standard (SNI). The community targeted at training in making soap is the PKK and the Women Farmer Group in Ababi Village, Abang District, Karangasem Regency. The training results showed that there was an increase in participants' knowledge into antibacterial soap and how to make it.
\end{abstract}

Keywords: Soap, Antibacterial, Cananga, VCO

\section{PENDAHULUAN}

Sabun antibakteri adalah sabun yang mengandung bahan aktif yang dapat menghambat pertumbuhan atau membunuh bakteri. Pada kesempatan ini dilakukan kegiatan pengabdian kepada masyarakat tentang pembuatan sabun antibakteri dengan penambahan VCO dan ekstrak bunga kenanga sebagai agen antibakteri. Sasaran kegiatan ini adalah kelompok wanita tani dan ibu-ibu PKK di Desa Ababi, Kecamatan Abang Karangasem.

\footnotetext{
${ }^{1}$ Jurusan Kimia FMIPA Universitas Udayana, susanah.rita@unud.ac.id

${ }^{2}$ Jurusan Kimia FMIPA Universitas Udayana

${ }^{3}$ Jurusan Kimia FMIPA Universitas Udayana

${ }^{4}$ Jurusan Kimia FMIPA Universitas Udayana
} 
Desa Ababi merupakan salah satu desa yang terletak di wilayah Kecamatan Abang, Kabupaten Karangasem. Bentuk wilayah desa ini berbeda-beda menurut letaknya. Sebelah utara Desa Ababi merupakan daerah dataran tinggi, sebelah timur adalah daerah dengan tanah berbukit kecil yang sebagian besarnya area persawahan. Sebelah baratnya adalah daerah datar. Bagian selatan merupakan daerah dataran rendah dan sawah. Sedangkan daerah bagian tengah Desa Ababi berbentuk tanah berbukit kecil (tidak datar).

Mata pencaharian utama penduduk Desa Ababi masih bertumpu pada sektor pertanian. Salah satu yang dihasilkan oleh masyarakat Desa ababi adalah kelapa. Oleh karena itu, pada bulan September 2017 telah dilakukan pelatihan untuk kelompok tani wanita tentang pembuatan minyak kelapa yang bernilai ekonomis tinggi yaitu Virgin Coconut Oil (VCO) di Banjar Dinas Kuhum Desa Ababi. Sebagai kelanjutan dari kegiatan tersebut, maka akan dilakukan pemanfaatan VCO tersebut sebagai bahan tambahan sabun antibakteri. Disamping itu, masyarakat juga menanam bermacam-macam bunga seperti kenanga (Bali: sandat), kamboja (Bali: Jepun), Gemitir, dan lain-lain sebagai sarana upacara. Bunga kenanga disamping mempunyai aktifitas sebagai antibakteri, juga merupakan bahan pewangi alami, sehingga bisa ditambahkan dalam pembuatan sabun antibakteri.

Sabun adalah suatu sediaan yang berfungsi sebagai pencuci pakaian dan pembersih kulit yang digunakan oleh masyarakat. Berbagai jenis sabun di pasaran beredar dalam bentuk yang bervariasi (Ari dan Budiyono, 2004). Salah satu bahan pembersih kulit yaitu sabun mandi. Sabun mandi merupakan bahan yang mengandung senyawa natrium atau kalium dengan asam lemak dari minyak nabati atau hewani, berbentuk padat, lunak atau cair, berbusa, dengan atau tanpa penambahan lain seperti pewangi dan bahan lainnya yang tidak membahayakan kesehatan serta tidak menimbulkan iritasi pada kulit (SNI, 1994).

Pemanfaatan sabun sebagai pembersih kulit semakin menjadi trend dan beragam. Keragaman sabun yang dijual secara komersial dapat dilihat pada jenis, warna,wangi, dan manfaat yang ditawarkan (Jaelani, 2009). Indonesia merupakan Negara tropis yang menyebabkan bakteri tumbuh dan berkembang secara cepat. Kulit yang kotor seharian, jika tidak dibersihkan maka bakteri akan mudah menginfeksi. Penggunaan sabun bakteri dijadikan sebagai solusi dari masalah bakteri ini. Sabun yang dapat membunuh bakteri dikenal dengan sabun mandi antibakteri.

Dewasa ini, sabun mandi antibakteri sangat diminati oleh masyarakat. Hal ini disebabkan karena dipercaya dapat membersihkan kulit, juga dapat mengobati dan/atau mencegah penyakit yang disebabkan oleh bakteri. Triclocarban merupakan zat antibakteri yang paling banyak digunakan dalam sabun mandi padat, namun menurut Badan Obat dan Makanan Amerika Serikat (FDA) jika digunakan dalam jangka panjang dapat menyebabkan resistensi bakteri terhadap antibiotik. Hal yang mesti diperhatikan adalah bahwa triclocarban bisa berbahaya baik bagi manusia maupun lingkungan, karena susunan kimianya mirip dengan beberapa jenis antibiotik. Salah satu cara menghindari efek samping yang ditimbulkan oleh triclocarban adalah penggunaan antibakteri dari bahan alam sebagai alternatif pengganti triclocarban. Penggunaan tanaman sebagai bahan aktif memiliki keunggulan antara lain relatif lebih aman, mudah diperoleh, tidak menimbulkan resistensi dan relatif tidak berbahaya (Carey, 2016; Nainggolan, 2017).

Penggunaan bahan alam sebagai alternatif pengganti triclocarban pada sabun diharapkan dapat menghambat pertumbuhan bakteri lebih efektif. Salah satu bahan alam yang berpotensi sebagai alternatif pengganti triclocarban pada sabun adalah Virgin Coconut Oil (VCO) dan ekstrak bunga kenanga (Cananga odorata). Tangwatcharin and Khopaibool (2012) melaporkan bahwa VCO dan asam laurat yang dikombinasikan dengan asam laktat mampu menghambat pertumbuhan bakteri Staphylococcus aureus. VCO juga dilaporkan dapat menghambat pertumbuhan Clostridium difficile, bakteri penyebab penyakit diare (Shilling et al., 2013). Dusturia et al. (2016) melaporkan bahwa perasan bunga kenanga bersifat antibakteri terhadap Staphylococcus aureus. Sree et al. (2015) melaporkan bahwa ekstrak n-butanol bunga kenanga mampu menghambat sangat kuat beberapa bakteri patogen pada manusia. Menurut Tan et al. (2015), Minyak atsiri bunga kenanga digunakan dalam aromaterapi dan diyakini efektif dalam mengobati depresi, tekanan darah tinggi, 
dan kecemasan. Sifat antimikroba dari minyak esensial dan ekstrak bunga kenanga telah diuji terhadap berbagai bakteri Gram positif dan negatif serta jamur patogen.

Ibu rumah tangga harusnya mengetahui tentang pentingnya sabun antibakteri untuk keluarga, apalagi jika mereka bisa membuat sendiri dalam skala rumahan atau home industry. Oleh karena itu pengabdian masyarakat tentang pembuatan sabun antibakteri sangat perlu dilakukan untuk menambah wawasan ibu-ibu tentang pembuatan sabun anti bakteri dengan bahan aktif VCO dan bunga kenanga.

\section{METODE PELAKSANAAN}

Metode yang digunakan dalam pelaksanaan program kegiatan kepada masyarakat adalah member materi pelatihan dan melakukan praktek tentang pembuatan sabun antibakteri dengan bahan tambahan VCO dan ekstrak bunga cendana sebagai agen antibakteri. Kegiatan telah dilakukan pada bulan Juli 2018 di hadapan ibu-ibu kelompok tani dan ibu-ibu PKK Desa Ababi.

Sabun dibuat dengan menggunakan bahan-bahan kimia seperti: bungan kenanga. asam stearat, $\mathrm{NaOH}$, gliserin, sukrosa, Cocamid DEA, $\mathrm{NaCl}$, akuades, alkohol, indikator metil orange, indikator fenolftalein, etanol, $\mathrm{KOH}$, dan $\mathrm{HCl}$. Bahan lain yang digunakan dalam penelitian ini adalah Virgin Coconut Oil (VCO), minyak zaitun, dan sabun antibakteri yang ada di pasaran. Sedangkan perlatan yang diperlukan adalah: seperangkat alat gelas, gunting, neraca analitik, satu set alat destilasi uap, termometer, klem dan statif, cawan petri, laminar air flow, inkubator, cotton bud, mikroskop, autoklaf, mistar, ose, aluminium foil, bunsen, kaki tiga, cetakan sabun, oven, desikator, ball filler, hotplate, panci, buret, kertas saring, penangas air, dan serbet.

Sampel bunga kenanga dicuci bersih dan dikeringkan. Sampel dipotong kecil-kecil, selanjutnya dikering-anginkan. Bunga kenanga yang sudah kering kemudian digiling menjadi serbuk. Sebanyak 500 g serbuk bunga kenanga dimaserasi dengan 2 liter etanol selama 2 hari, selanjutntnya ekstrak dipekatkan, Formula sabun yang digunakan menggunakan formula terbaik berdasarkan penelitian yang telah dilakukan oleh Rita dkk. (2018) yang disajikan dalam Tabel 2.1.

Tabel 2.1 Formula sabun dari VCO dan bunga kenanga

\begin{tabular}{cccc}
\hline No. & Nama Bahan & Kegunaan & Bobot Sediaan (gr) \\
\hline 1. & Virgin Coconut Oil $($ VCO) & Basis sabun & 50 \\
2. & Minyak Kelapa & Basis sabun & 10 \\
3. & Asam stearat & Pengeras & 21 \\
4. & NaOH & Untuk membentuk sabun & 60,9 \\
5. & Etanol $96 \%$ & Pengawet & 45 \\
6. & Gliserin & Humektan (pelembab) & 39 \\
7. & Sukrosa & Transparant agent & 45 \\
8. & Cocamid-DEA & Surfaktan & 3 \\
9. & NaCl & Agen pembentukan busa & 0,6 \\
10. & Pewarna makanan & Pewarna & Secukupnya \\
11. & Ekstrak Cananga & Zat Aktif & 1 \\
12. & Fragrance Oil (Cananga) & pengharum & Secukupnya \\
\hline
\end{tabular}

Proses pembuatan sabun diawali dengan mencampurkan fraksi lemak, yaitu asam stearat dan minyak VCO dan minyak zaitun dengan alkali yaitu $\mathrm{NaOH} 30 \%$ pada suhu $35^{\circ} \mathrm{C}$. Pada saat penambahan $\mathrm{NaOH}$ ini, adonan akan menjadi keras dan lengket yang menunjukkan terbentuknya stok sabun. Kemudian ke dalam stok sabun ditambahkan bahan tambahan lainnya seperti gliserin, sukrosa, cocamid-DEA, $\mathrm{NaCl}$, akuades dan minyak atsiri serai dapur. Adonan kemudian diaduk hingga homogen. Sabun dituangkan ke dalam cetakan 
dan didiamkan selama \pm 24 jam pada suhu ruang. Setelah sabun didiamkan selama 3-4 minggu (proses aging), selanjutnya dilakukan evaluasi mutunya yang mengacu pada SNI-06-3532-1994 mengenai syarat mutu sabun mandi padat yang meliputi kadar air, jumlah asam lemak tersabunkan, asam lemak bebas/alkali bebas, lemak tak tersabunkan, dan minyak mineral.

\section{HASIL DAN PEMBAHASAN}

Pengabdian kepada masyarakat dengan judul "Pemanfaatan VCO dan ekstrak bunga kenanga dalam pembuatan sabun antibakteri di Desa Ababi Kecamatan Abang Karangasem" telah dilaksanakan pada hari Kamis tanggal 19 Juli 2018, bertempat di Aula Kantor Kepala Desa Ababi. Kegiatan dihadiri oleh 38 ibu-ibu yang tergabung dalam kelompok wanita tani dan PKK. Selama kegiatan peserta sangat antusias mendengarkan penjelasan tentang prosedur pembuatan sabun dan melakukan praktek secara langsung (Gambar 3.1)
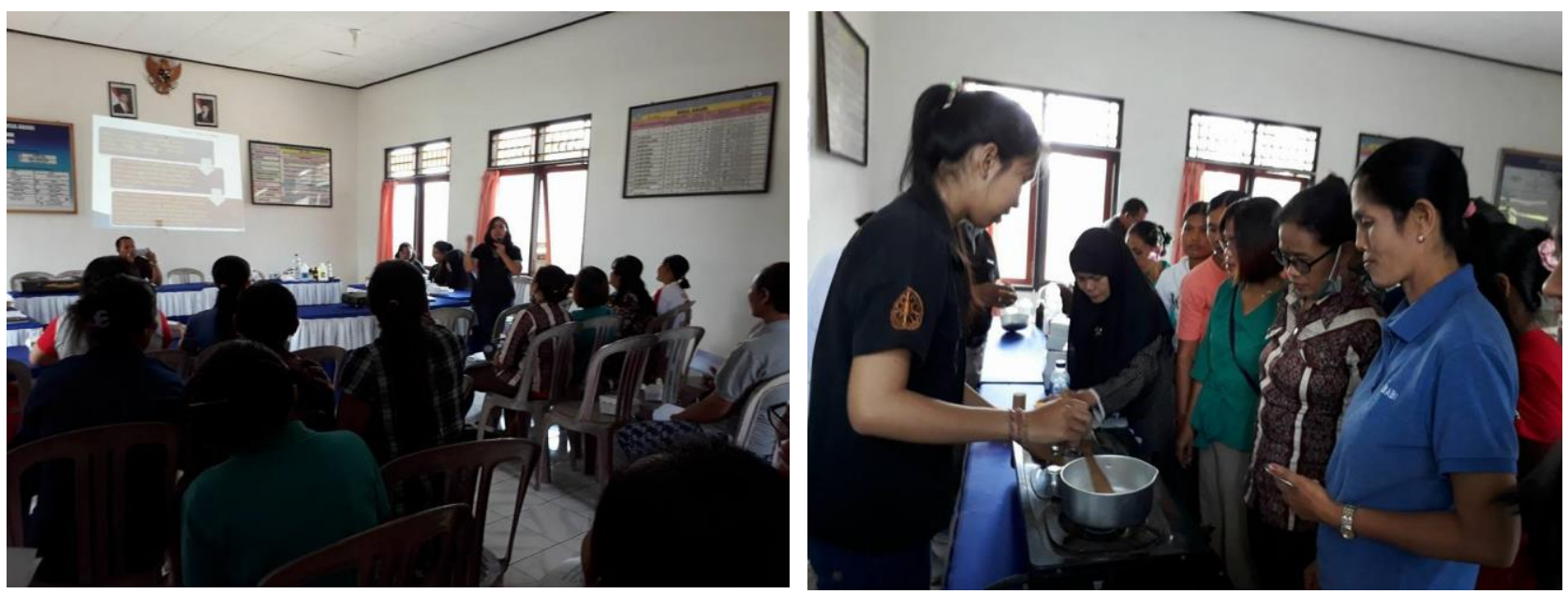

Gambar 3.1 Penjelasan prosedur pembuatan sabun dan melakukan praktek secara langsung

Sabun yang dibuat merupakan sabun transparan dengan bahan utama VCO (Virgin Coconut oil). VCO dikenal mempunyai banyak khasiat, salah satunya sebagai antibakteri (Tangwatcharin and Khopaibool, 2012; Shilling et al., 2013), sehingga sangat baik digunakan sebagai bahan sabun antiseptic. Disamping itu, ekstrak bunga kenanga juga ditambahkan ke dalam campuran bahan-bahan sabun. Selain sebagai pengharum, ekstrak dan minyak atsiri bunga kenanga juga berkhasiat sebagai antibakteri (Dusturia et al., 2016; Sree et al., 2015). Campuran sukrosa dan gliserin ditambahkan untuk membuat sabun menjadi transparan. Mutu sabun yang dihasilkan telah memenuhi Standar Nasional Indonesia (SNI) (Tabel 3.1).

Tabel 3.1 Hasil analisis mutu sabun padat transparan dari VCO

\begin{tabular}{lcc}
\hline \multicolumn{1}{c}{ Parameter } & Hasil Analisis Mutu Sabun & Standar SNI \\
\hline Kadar air (\%) & 14,051 & Maks $15^{*}$ \\
Jumlah asam lemak tersabunkan (\%) & 73,5 & $>71^{*}$ \\
Asam lemak bebas/alkali bebas (\%) & $0,1 * * *$ & $<2,5 / \mathrm{Maks} 0,1^{*}$ \\
Lemak tak tersabun kan (\%) & 2,25 & Maks 2,5* \\
Minyak mineral & Negatif & Negatif \\
Derajat keasaman $(\mathrm{pH})$ & 10,2 & $9-11^{* *}$ \\
\hline
\end{tabular}

Keterangan :

* : (SNI 06-3532-1994)

** :ASTMD 1172-95 (2001)

***: Alkali bebas 
Pencampuran antara fraksi lemak, yaitu asam stearat dan minyak VCO dan minyak zaitun dengan alkali yaitu $\mathrm{NaOH} 30 \%$ bertujuan untuk membuat stok sabun. Setelah stok sabun terbentuk (trace), ditambahkan bahan-bahan lainnya seperti gliserin, sukrosa, cocamid-DEA, $\mathrm{NaCl}$, dan minyak atsiri serai dapur. Trace adalah kondisi dimana massa sabun telah terbentuk yang ditandai dengan massa sabun mengental.

Sabun yang telah dibuat baru bisa digunakan setelah masa aging selama 2-4 minggu. Dari kegiatan ini diharapkan peserta bisa mempraktekkan sendiri di rumah yang selanjutnya membuat dalam skala home industry untuk memperoleh penghasilan tambahan. Sebelum kegiatan pembuatan sabun ini kelompok wanita tani sudah diajari cara pembuatan VCO, sehingga masalah bahan utama sabun tidak menjadi masalah. Akan tetapi bahan utama lain seperti $\mathrm{NaOH}$ harus dibeli di Denpasar, karena di Karangasem belum ada penjual bahan kimia. Sabun dibuat dari reaksi antara minyak atau lemak (triglserida) dengan basa natrium hidroksida $(\mathrm{NaOH})$, yang dikenal dengan soda api, baik dengan cara dingin maupun panas. Bahan-bahan lain ditambahkan untuk tujuan tertentu, misalkan ditambahkan gliserin untuk pelembab, ditambahkan bahan aktif untuk sabun dengan khasiat tertentu, dan sebagainya. Reaksi pembuatan dapat dilihat pada Gambar 3.2, sedangkan sabun yang dihasilkan dapat dilihat pada Gambar 3.3.

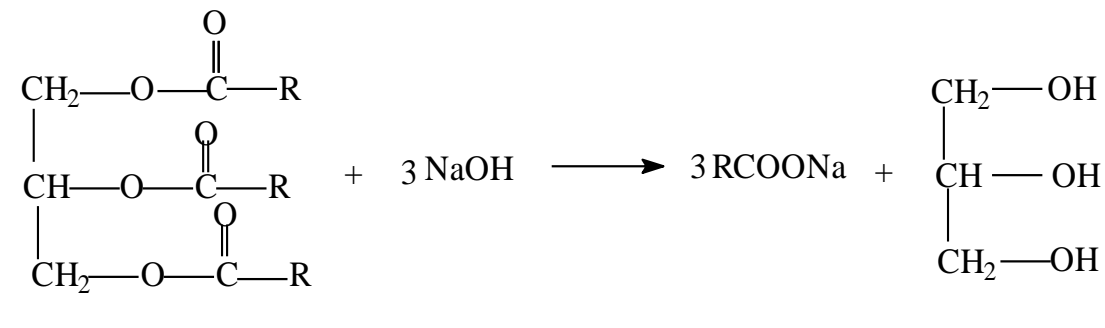

$\begin{array}{llll}\text { Trigliserida } & \text { Basa } & \text { Sabun }\end{array}$

Gambar 3.2 Reaksi saponifikasi trigliserida dengan NaOH (Kolakowska, 2010)
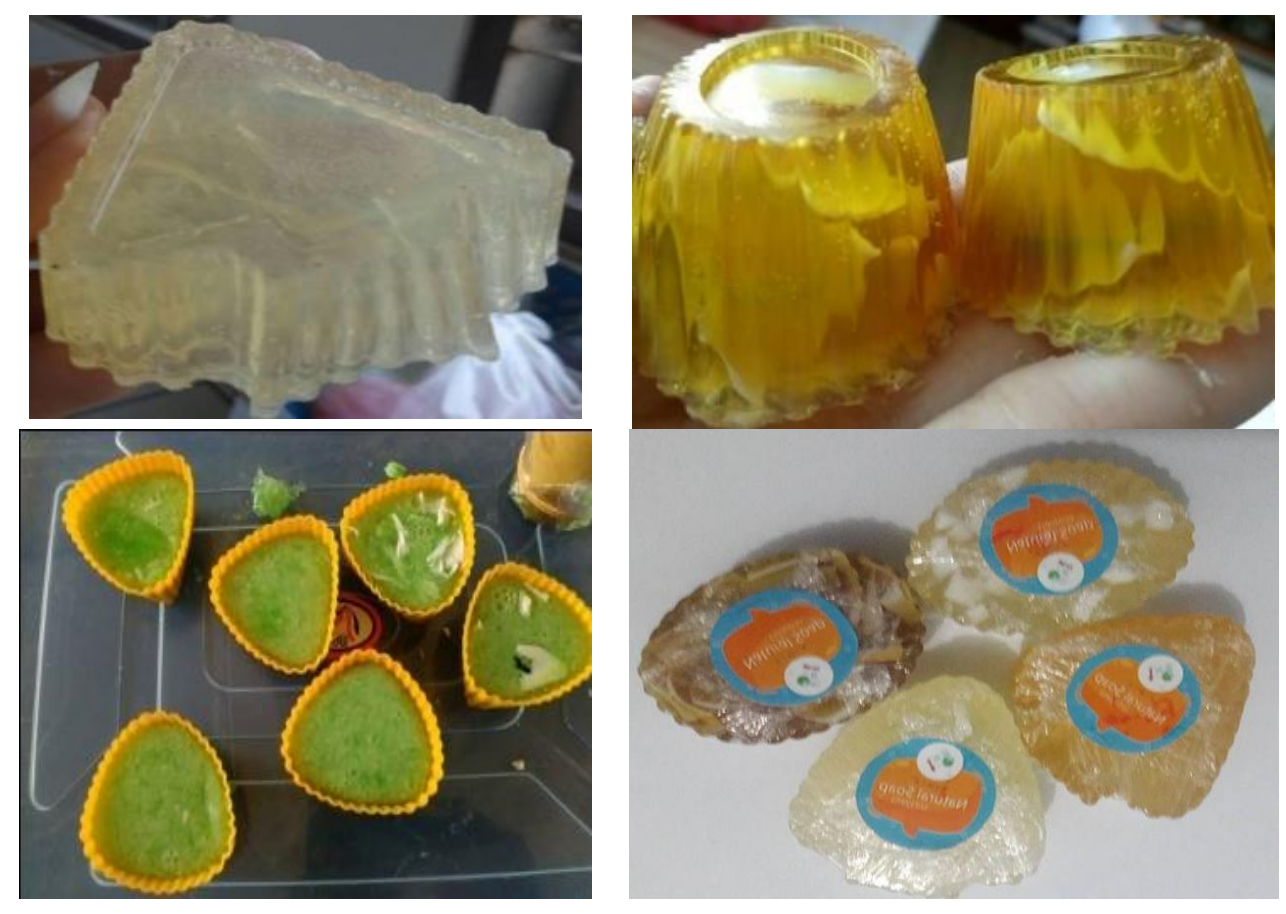

Gambar 3.3 Sabun Antibakteri dengan bahan aktif VCO dan ekstrak bunga kenanga 


\section{KESIMPULAN DAN SARAN}

Berdasarkan hasil evaluasi terhadap kegiatan pengabdian kepada masyarakat yang telah dilakukan, maka disimpulkan bahwa kelompok wanita tani dan ibu-ibu PKK Desa Ababi Kecamatan Abang Kabupaten Karangasem memberikan respon yang positif terhadap pelaksanaan pengabdian tentang pembuatan sabun antibakteri dengan bahan aktif VCO dan ekstrak bunga kenanga. Hal ini ditunjukkan oleh banyaknya pertanyaan yang masuk pada saat kelompok wanita tani dan ibu-ibu PKK mendengarkan penjelasan tentang prosedur pembuatan sabun, serta antusias para peserta dalam melakukan praktek secara langsung.

Kegiatan ini perlu dilanjutkan dengan produk yang lebih beragam, sehingga ibu-ibu Desa Ababi bisa membuat sabun sendiri untuk berwirausaha. Perhitungan besarnya biaya yang dikeluarkan dalam pembuatan sabun ini juga perlu dilakukan, agar bisa diketahui berapa harga 1 buah sabun apabila akan berwirausaha.

\section{UCAPAN TERIMA KASIH}

Penulis mengucapkan terima kasih kepada Kepala Desa Ababi dan seluruh stafnya yang menyediakan tempat pengabdian dan mengundang kelompok wanita tani dan ibu-ibu PKK untuk mengikuti kegiatan ini; Lembaga Penelitian dan Pengabdian kepada Masyarakat Universitas Udayana yang telah menyediakan segala keperluan yang terkait dengan pengabdian ini; serta kepada semua pihak yang telah membantu demi terselesainya kegiatan ini. Pengabdian ini dibiayai oleh DIPA PNBP Universitas Udayana Tahun Anggaran 2018, melalui skema Udayana Mengabdi, dengan kontrak Nomor: 384-59/UN14.4.A/PM/2018, tanggal 29 Maret 2018

\section{DAFTAR PUSTAKA}

Ari, W. dan Budiyono, 2004, Pembuatan Sabun Cair Dengan Bahan Dasar Alkil Benzen Sulfonat. [cited 2017 Maret 24]. Available from: http://www.angelfire.com.

ASTM Standards, 2001, Designation : D 172-92, Standard Guide for pH of Aqueous Solutions of Soap and Detergents, West Conshocken, PA, United States.

Carey, D.E., Zitomer, D.H., Hristova, K.R., Kappell, A.D., McNamara, P.J. 2016. Triclocarban Influences Antibiotic Resistance and Alters Anaerobic Digester Microbial Community Structure. Environ. Sci. Technol., 50 (1): 126-134.

Dusturia, N., Hikamah, S.R., Sudiarti, D. 2016. Efektivitas Antibakteri Bunga Kenanga (Cananga odorata) dengan Metode Konvensional terhadap Pertumbuhan Staphylococcus aureus. Bioshell, 5(1): 324 332 .

Jaelani. 2009. Ensiklopedi Kosmetika Nabati, Pustaka Populer Obor, Jakarta.

Kolakowska, A., 2010, Chemical and Functional Properties of Food Lipids, CRC Press, Berlin.

Nainggolan, S.Y. 2017. Benarkah Sabun Antibakteri Mempan Bunuh Kuman? [cited 2018 Pebruary 16]. Available from: http://rona.metrotvnews.com/kesehatan/8N08oqzN-benarkah-sabun-antibakterimempan-bunuh-kuman.

Rita, W.S., Vinapriliani, N.P.E., Gunawan, I.W.G. 2018. Formulasi Sediaan Sabun Padat Minyak Atsiri Serai Dapur (Cymbopogon citratus DC.) sebagai Antibakteri terhadap Escherichia coli dan Staphylococcus aureus. Artikel Cakra Kimia (belum terbit).

Shilling, M., Matt, L., Rubin, E., Visitacion, M.P., Haller, N.A., Grey, S.F., Woolverton, C.J. 2013. Antimicrobial Effects of Virgin Coconut Oil and Its Medium-Chain Fatty Acids on Clostridium difficile. J. Med. Food, 16 (12): 1079-1085.

Sree, S.K., Anudeep, M., Ramana, Ch.B., Bhaskar, Ch. 2015. Screening of antimicrobial activity of flower extracts on human bacterial pathogens. Journal of Pharmacognosy and Phytochemistry, 3(6): 153156. 
Standar Nasional Indonesia. 1994. Sabun Mandi: No. 06-3532-1994, Badan Standar Nasional, Jakarta.

Tangwatcharin, P. and Khopaibool, P. 2012. Activity of Virgin Coconaut Oil, Lauric Acid or Monolaurin in Combination with Lactic Acid against Staphylococcus aureus. Southeast Asian J. Trop. Med. Public Health, 43(4): 969-985.

Tan, L.T.H, Lee, L.H., Yin, W.F., Chan, C.K., Kadir, H.A., Chan, K.G., Goh, C.K. 2015. Review Article: Traditional Uses, Phytochemistry, and Bioactivities of Cananga odorata (Ylang-Ylang). Hindawi Publishing Corporation, Evidence-Based Complementary and Alternative Medicine. 